Teologia i Moralność, volumen 12(2017), numer 2(22)

doi: 10.14746/tim.2017.22.2.9

JACEK CZERNIAK

Ośrodek Wsparcia Płodności NaProTechnologia

w Licheniu Starym

\title{
Naprotechnologia - dobra diagnostyka i skuteczne leczenie
}

Historia naprotechnologii (ang. Natural Procreative Technology), nowej dziedziny wiedzy medycznej poświęconej zdrowiu prokreacyjnemu kobiety, jest nieodłącznie związana z doktorem Thomasem Hilgersem z Omaha w stanie Nebraska (USA). Jest on praktykującym lekarzem ginekologiem-położnikiem, obecnie dyrektorem Instytutu Papieża Pawła VI w Omaha (Pope Paul VI Institute for the Study of Human Reproduction), profesorem Creighton University School of Medicine, członkiem prestiżowego Amerykańskiego Towarzystwa Chirurgów Reprodukcyjnych. W latach siedemdziesiątych ubiegłego wieku jako młody adept sztuki medycznej odpowiedział na przesłanie encykliki papieża Pawła VI Humanae vitae (O zasadach moralnych w dziedzinie przekazywania życia ludzkiego). Ojciec Święty zwrócił się do ludzi nauki, aby opracowali metodę naturalnego planowania rodziny, która odpowiadałaby wymogom etycznym w aspekcie nauki Kościoła:

Pragniemy teraz zwrócić się ze słowami zachęty do ludzi nauki, którzy „wiele mogą oddać usług dobru małżeństwa i rodziny oraz spokojowi sumień, jeśli przez wspólny wkład swych badań będą się gorliwie starać wszechstronnie wyjaśnić różne warunki sprzyjające właściwemu regulowaniu ludzkiej rozrodczości”. Przede wszystkim tego należy pragnąć, aby - zgodnie z życzeniem wyrażonym już przez Piusa XII - medycyna zdołała wypracować wystarczająco pewną metodę poprawnej moralnie regulacji poczęć, opartej na uwzględnianiu naturalnego rytmu płodności. W ten sposób ludzie nauki, a w szczególności uczeni katoliccy, wykażą ze swej strony, iż rzeczy mają się tak, jak Kościół naucza, że mianowicie „nie może być rzeczywistej sprzeczności między boskimi prawami dotyczącymi z jednej strony przekazywania życia, a z drugiej pielęgnowania prawdziwej miłości małżeńskiej”’.

\footnotetext{
${ }^{1}$ Paweł VI, Humanae vitae, (25 lipiec 1968).
} 
Techniki Wspomaganego Rozrodu Assisted Reproduction Technology (ART)

- Inseminacje domaciczne(IUI)

- Zapłodnienie pozaustrojowe (in vitro, ICSI)

- Wspomaganie osób trzecich (Third Party Assisted ART)

- Dawstwo gamet (Sperm/Egg Donation)

- Macierzyństwo zastępcze Surrogates and Gestational Carriers)
Naprawcza Medycyna Prokreacji Restorative Reproductive Medicine(RRM)

- Metody Rozpoznawania Płodności Fertility Awarreness Based Methods(FABMethods)

- Creighton Model Fertility Care System-NaProTECHNOLOGY

- Metoda owulacji Billingsa

- Metody objawowo-termiczne

$\checkmark \quad$ Podwójnego sprawdzenia

$\checkmark \quad$ Kippleyów

$\checkmark \quad$ Roetzera

$\checkmark$ Polska

Marquette Method

Hilgers podjął badania w dziedzinie ludzkiej płodności, a jako punkt wyjścia posłużyła mu metoda owulacji Bilingsa. Kilkanaście lat żmudnych badań naukowych weryfikowanych metodami statystycznymi i praktyką kliniczną pozwoliły na opracowanie nowej metody naturalnego planowania rodziny: Creighton Model Fertility Care System (ang. fertility care - 'troska o płodność'), która jest wystandaryzowaną i zmodyfikowaną metodą obserwacji cyklu Bilingsa. Nowa metoda naturalnego planowania rodziny jest precyzyjna, powtarzalna i uniwersalna. Drobiazgowa analiza kliniczna i statystyczna uzyskanych w latach 1976-1985 obserwacji cykli miesiączkowych pokazała, że tysiące kobiet, które się obserwowały, mają bardzo podobne objawy i podobne modele chorowania. Już w tym momencie objawił się geniusz doktora Hilgersa, który nie poprzestał na tym osiągnięciu, wykazał ogromną determinację i mimo braku wsparcia kolegów lekarzy, a wręcz wrogości i wściekłych ataków środowisk nieprzyjaznych ochronie życia o mentalności antykoncepcyjnej w Stanach Zjednoczonych, kontynuował swoje badania. Udało się powiązać obserwację biomarkerów cyklu kobiecego z przebiegiem fizjologicznych zmian hormonalnych i czynnościowych w organizmie kobiecym. To z kolei pozwoliło na zastosowanie interwencji medycznych, w tym leczenia farmako- 
logicznego i chirurgicznego w przypadkach rozpoznanej patologii, w ścisłym powiązaniu z przebiegiem cyklu miesiączkowego. Tak powstała naprotechnologia: metoda diagnostyczno-terapeutyczna wykorzystująca $\mathrm{w}$ diagnostyce stanu zdrowia i monitorowaniu leczenia obserwacje objawów płodności na podstawie Creighton Model Fertility Care System. W 2004 roku został wydany podręcznik The Medical and Surgical Practice of NaProTECHNOLOGY (Medyczna i chirurgiczna praktyka naprotechnologii - thum. atora) będący pełnym kompendium wiedzy $w$ tej dziedzinie i jednocześnie podsumowaniem wieloletniej pracy i badań profesora oraz jego zespołu. Nie można przecenić znaczenia tego odkrycia, gdyż jest to pierwsza metoda naturalnego planowania rodziny, która mogła zostać wykorzystana w profesjonalnej diagnostyce i leczeniu zaburzeń płodności.

Poznanie naprotechnologii miało również ważne praktyczne znaczenie dla autora niniejszego opracowania, który jako nauczyciel i instruktor metody wielowskaźnikowej podwójnego sprawdzenia (tzw. angielskiej) z wieloletnim doświadczeniem, po raz pierwszy otrzymał do ręki narzędzie, nie tylko do obserwacji (jak to ma miejsce w innych metodach naturalnego planowania rodziny), ale również do prowadzenia profesjonalnej diagnostyki i terapii.

Rycina 1 wskazuje na miejsce Creighton Model Fertility Care System i naprotechnologii w nurcie naprawczej medycyny prokreacji (Restorative Reproductive Medicine), w odróżnieniu od tak zwanych metod wspomaganego rozrodu, nieakceptujących szacunku dla życia ludzkiego. W naprawczej medycynie prokreacji, której jednym z głównych nurtów jest naprotechnologia, kładzie się nacisk na kształtowanie nowej kultury życia ludzkiego, na poszanowanie dla praw dziecka, które poczyna się drogą naturalną, w założeniach jest też szacunek dla nauki Kościoła katolickiego. W aspekcie czysto lekarskim naprawcza medycyna prokreacji to medycyna regeneracyjna, naprawcza w zakresie płodności i przekazywania życia, która skupia się na badaniach podstawowych, diagnostyce i leczeniu nieprawidłowości, przywracając i optymalizując normalne funkcje rozrodcze. Celem takiego postępowania jest przywrócenie zdrowia, a nie tylko uzyskanie potomstwa za wszelką cenę, jak ma to miejsce w przypadku technik wspomaganego rozrodu (Assisted Reproduction Technology). Należy jednak zaznaczyć, że naprotechnologia nie jest metodą przeznaczoną tylko dla katolików, ponieważ opiera się na uniwersalnej fizjologii człowieka.

\section{Naprotechnologia w Licheniu Starym}

Skąd naprotechnologia w Licheniu Starym? Poradnia powstała w Licheniu Starym jako kolejny pomysł ojców marianów na realizację dzieł miłosierdzia obok tych już istniejących i przynoszących konkretne owoce, to znaczy: 
Centrum Pomocy Rodzinie oraz oddziału opieki paliatywnej - hospicjum. Zainteresowanie naprotechnologią pojawiło się wiosną 2010 roku, pomysł stworzenia ośrodka przywieźli ze spotkania z dr. Piotrem Klimasem, jednym z pierwszych lekarzy naprotechnologów w Polsce, ks. kustosz Wiktor Gumienny oraz ks. dr Piotr Kieniewicz. Już jesienią tego roku grupa przyszłych instruktorów, lekarz i kapłan rozpoczęli kilkumiesięczne szkolenie, udając się do źródła nowej metody, do Instytutu Ludzkiej Rozrodczości im Papieża Pawła VI w Omaha w Nebrasce, założonego i prowadzonego przez profesora Thomasa Hilgersa. Był to czas intensywnej nauki i szkolenia, ale i spotkań oraz wymiany doświadczeń z innymi instruktorami i lekarzami praktycznie ze wszystkich kontynentów, bo tak rozległe jest zainteresowanie naprotechnologią. Kontynuacja szkolenia miała miejsce po powrocie w Polsce pod okiem superwizorów z ośrodka w Omaha oraz ponownie wiosną 2011 roku w Stanach Zjednoczonych. Już na początku grudnia 2010 roku w Licheniu rozpoczęła działalność Poradnia Wsparcia Płodności. Dnia 3 grudnia 2010 w Poznaniu odbyła się konferencja „Zdrowie prokreacyjne. NaProTECHNOLOGY w diagnozowaniu i leczeniu niepłodności”, której kontynuacją były warsztaty naprotechnologii 4-5 grudnia 2010 roku w Licheniu Starym z udziałem prekursora tej metody w Europie, doktora Phila Boyle'a.

Praktyka szybko pokazała, jak bardzo potrzebny jest na miejscu lekarz ginekolog-położnik. W 2013 roku dzięki determinacji gospodarzy miejsca powstał Ośrodek Wsparcia Płodności „NaProTechnologia” z profesjonalnie wyposażonym gabinetem ginekologicznym, udzielający porad nie tylko w problemach związanych $\mathrm{z}$ niepłodnością, ale również służący $\mathrm{w}$ miarę swoich możliwości wszystkim potrzebującym pomocy pacjentkom. W ośrodku pracuje obecnie trzech intruktorów modelu Creighton, czterech lekarzy specjalistów ginekologów, w tym dwóch ze specjalizacją w dziedzinie endokrynologii oraz lekarz specjalista chorób wewnętrznych. Należy dodać, że wszyscy lekarze przeszli szkolenie i uzyskali tytuł konsultanta medycznego w dziedzinie naprotechnologii. Obok podstawowych badań ginekologicznych prowadzony jest monitoring ultrasonograficzny owulacji oraz wykonywane są pierwsze badania histerosalpingografii (HSG). Naprotechnologia rozwija się dynamicznie w Polsce od 2007 roku. Ośrodek Wsparcia Płodności „NaProTechnologia” jest podmiotem leczniczym $\mathrm{w}$ trakcie rozwoju - istnieją plany poszerzenia zakresu bazy i świadczeń medycznych ściśle związanych z tą dziedziną wiedzy medycznej. 


\section{Etapy postępowania w naprotechnologii w sytuacji niepłodności}

Aby dobrze zrozumieć naprotechnologię, pracę zespołu: instruktorów modelu Creighton i lekarzy konsultantów medycznych, należy mieć na uwadze dwutorowość, z którą w tym przypadku mamy do czynienia Bardzo celnie i przystępnie thumaczy to ks. Piotr Kieniewicz MIC:

Dr Hilgers [...] opracował ustandaryzowaną metodę obserwacji symptomów płodności, która stała się punktem wyjścia dla zaawansowanej diagnostyki i terapii. W ten sposób praca jego zespołu zaowocowała powstaniem dwóch gałęzi jednego drzewa. Pierwszą gałęzią jest metoda obserwacji, a ściślej zintegrowany system opieki nad płodnością oparty o Model Creighton (nazwa pochodzi od uniwersytetu, na którym pracuje Dr Hilgers). Drugą gałęzią jest system diagnostyczno-terapeutyczny, określany mianem NaProTECHNOLOGY, czy jak przyjęło się niekiedy mówić w Polsce: naprotechnologia. Nazwa ta jest skrótem od słów Natural Procreative Technology, czyli technologia naturalnej prokreacji i [...] w prosty sposób wyraża logikę metody. Chodzi o zastosowanie nowoczesnej technologii, by przywrócić fizjologiczny stan płodności, zgodny z naturą ludzkiego ciała²

Praktycznie więc, z jednej strony instruktorzy prowadzą dydaktykę, ucząc wiedzy o płodności, na podstawie doskonałego narzędzia, jakim jest Creighton Model Fertility Care System (CrMS). Creighton Model Fertility Care System jest to jedna z metod rozpoznawania płodności, ale dedykowana naprotechnologii. Jest to wystandaryzowana i zmodyfikowana metoda obserwacji cyklu Bilingsa, która jest precyzyjna, powtarzalna i uniwersalna, co ułatwia prace lekarzom. Drugi tor, który jest równoległy, to są wizyty u lekarza konsultanta medycznego naprotechnologii. Lekarz prowadzi diagnostykę na podstawie zapisu biomarkerów cyklu kobiecego i zleca badania oraz leczenie we współpracy z cyklem. W związku z tym badania i interwencje medyczne nie są przypadkowe, a ściśle korelowane z przebiegiem cyklu konkretnej kobiety. Proces diagnostyczno-leczniczy w przypadku niepłodności może trwać od kilku do kilkunastu miesięcy i przedstawia się w zarysie w opisany poniżej sposób.

\section{Krok pierwszy}

Pierwsze spotkanie z instruktorem jest to tzw. sesja wprowadzająca. Jeżeli po tym spotkaniu para małżeńska lub kobieta decyduje się rozpocząć naukę, odbywa się osiem spotkań z instruktorem w ciągu 12 miesięcy. Najważniejsze

${ }^{2}$ P. Kieniewicz, NaProTECHNOLOGY, w: P. Kieniewicz, Bioetyczny labirynt, Licheń Stary 2013, s. 90-91. 
są jednak pierwsze trzy miesiąc - czas najbardziej intensywnej nauki prowadzenia obserwacji i zapisu cyklu na wystandaryzowanej karcie zapisu według ściśle skatalogowanych właściwości.

W czasie spotkań z instruktorem modelu Creighton para uczy się:

- prowadzić prawidłowe obserwacje;

- zapisywać obserwacje w czytelny dla lekarza konsultanta medycznego sposób;

- wyznaczać prawdopodobny dzień owulacji;

- określać czas płodności i niepłodności;

- określać właściwy czas na przeprowadzanie badań;

- wykrywać nieprawidłowości, wskazujące na zaburzenia zdrowia ginekologicznego i prokreacyjnego (problemy hormonalne, stany zapalne);

- zauważać postępy w leczeniu na podstawie przeprowadzanych obserwacji.

Należy w tym miejscu podkreślić liczne zalety Creighton Model Fertility Care System, który jest systemem:

- profesjonalnym;

- dostosowanym do konkretnej sytuacji użytkownika;

- medycznie bezpiecznym;

- moralnie godziwym;

- łatwym do nauczenia;

- wiarygodnym;

- współpracującym z naturalnym cyklem kobiety;

- stosowanym wspólnie przez męża i żonę;

- szanującym godność kobiety i integralność małżeństwa;

- mającym bardzo szerokie zastosowanie;

- precyzyjnie rozpoznającym dni płodne i niepłodne;

- niezbędnym w celu obserwowania i zachowywania zdrowia prokreacyjnego kobiety.

\section{Krok drugi}

Zwykle, po uzyskaniu ustabilizowanego zapisu 2-3 cykli miesiączkowych, można równolegle przekazać parę pod opiekę kompetentnego lekarza. Lekarz, na podstawie uzyskanych w zapisie karty CrMS informacji oraz przeprowadzonych wstępnych badań, obejmujących szczegółowy wywiad zdrowotny oraz badanie przedmiotowe, podejmie działania według precyzyjnie opracowanych standardów postępowania. 


\section{Etap I. Diagnostyka - próba znalezienia przyczyny zaburzeń stanu zdrowia}

$\mathrm{Na}$ tym etapie postępowania lekarz podejmuje działania mające na celu identyfikację problemu zdrowotnego, na co przeznaczony jest czas 2-6 miesięcy. Pamiętamy, że równolegle, zgodnie z planem nadal mają miejsce spotkania z instruktorem CrMS - kontynuacja nauki Modelu Creighton, interpretacja zapisu kolejnych cykli. Lekarz w zależności od wskazań w konkretnej sytuacji klinicznej zleca badania, które obejmują:

- diagnostykę hormonalną (w korelacji z przebiegiem cyklu oznaczany jest panel hormonów płciowych, hormony tarczycy i beta-endorfiny) oraz niezbędne podstawowe badania laboratoryjne,

- diagnostykę obrazową - badanie ultrasonograficzne, w tym monitoring owulacji, zaburzenia owulacji wykrywane w ultrasonografii to: niedojrzały pęcherzyk, częściowe pękanie pęcherzyka, luteinizacja niepękniętego pęcherzyka, opóźnione pękanie pęcherzyka, brak wzgórka jajonośnego;

- badanie nasienia z zastosowaniem specjalnego zbiorniczka Seminal Collection Device, który umożliwia pobranie próbki nasienia do badania podczas naturalnego współżycia, a nie poprzez masturbację. Następnie w czystym pojemniku dostarcza się próbkę do laboratorium. Taka metoda pobrania nie tylko respektuje integralność płciową i godność mężczyzny, ale też daje lepszej jakości informację, bo dotyczącą naturalnego kontekstu wytrysku (wyniki badań naukowych potwierdzają wyższą wartość próbki nasienia pobranego $\mathrm{w}$ ten sposób, w stosunku do nasienia pobranego w trakcie masturbacji) ${ }^{3}$;

- diagnostykę zabiegową, a w tym:

- selektywną histerosalpingografię, badanie mające na celu uwidocznienie jamy macicy i jajowodów;

- przezszyjkowe cewnikowanie jajowodów;

- Near-Contact Laparoscopy - laparoskopię tzw. bliskiego kontaktu, tj. w dużym powiększeniu; jest to procedura obrazowania miednicy, w której chirurg-ginekolog cierpliwie i bardzo uważnie oraz wykonując określoną rutynową sekwencję działań, ogląda narządy wewnętrzne w poszukiwaniu patologii. Duże zbliżenie i użycie obrazu wideo pozwala lekarzowi dostrzec wiele szczegółów i nieprawidłowości, któ-

${ }^{3}$ M. Barczentewicz, Naprotechnology jako narzędzie diagnostyki i leczenia niepłodności $i$ innych chorób, w: Naturalne planowanie rodziny w ujęciu wybranych dyscyplin naukowych, red. W. Wieczorek i in, Lublin 2008, s. 231. 
re nie zostały dostrzeżone $\mathrm{w}$ tradycyjnym badaniu laparoskopowym. Skuteczne zastosowanie laparoskopii „bliskiego kontaktu” wymaga dobrego szkolenia $\mathrm{w}$ tym zakresie oraz doświadczenia $\mathrm{w}$ powtarzaniu procedur ${ }^{4}$.

\section{Etap II. Leczenie przyczynowe trwa 1-6 miesięcy}

Na tym etapie postępowania nadal równolegle prowadzone są obserwacje cyklu według Modelu Creighton oraz w zależności od potrzeb w konkretnej sytuacji klinicznej różne metody leczenia:

\section{A. Leczenie zachowawcze}

1. Suplementacja hormonalna w przypadku niedoborów:

- współpracująca z cyklem progesteronowa terapia zastępcza (ang. skrót CPRT): stosuje się preparaty w postaci roztworu progesteronu do wstrzykiwań, tabletek dopochwowych, tabletek podjęzykowych, kapsułek miękkich. W przypadku niedoboru podaje się preparaty progesteronu w fazie poowulacyjnej, a w klasycznym postępowaniu ginekologicznym progesteron stosuje się w konkretnym dniu danego cyklu. Jest to postępowanie nieprawidłowe, gdyż faza przedowulacyjna ma zmienną długość (owulacja tylko w około $13,5 \%$ cykli ma miejsce w 14 dniu cyklu). Progesteron podany w przedowulacyjnej fazie cyklu nie tylko nie spełni swojego zadania, ale dodatkowo zaburzy $\mathrm{cykl}^{5}$;

- iniekcje ludzkiej gonadoptropiny kosmówkowej (HCG) ${ }^{6}$;

- estrogenowa terapia zastępcza (ang. skrót CERT) w przypadku niedoboru estrogenów ${ }^{7}$.

2. Antybiotykoterapia przy infekcjach (najczęściej celowana, poprzedzona badaniem bakteriologicznym).

3. Stymulacja jajeczkowania przy nieprawidłowej owulacji (klomifen).

${ }^{4}$ T.W. Hilgers, Diagnostic Laparoscopy: "Near Contact"'approach, w: tenże, The Medical and Surgical Practice of NaProTECHNOLOGY, Omaha [USA, Nebraska] 2004, s. 845-862.

${ }^{5}$ T.W. Hilgers, The NaProTECHNOLOGY Revolution. Unleashing the Power in a Woman's Cycles, New York 2010, s. 106-110.

${ }^{6}$ Tamże, s. 110.

${ }^{7}$ Tamże, s. 110-114. 
4. Uzupełnianie niedoborów beta-endorfin - terapia uzupełniająca w przypadku potwierdzenia niedoborów beta-endorfin, szczególnie w sytuacji współistnienia nasilonych objawów zespołu przedmiesiączkowego, podaje się bardzo małe dawki naltrexonu (LND) ${ }^{8}$.

Jeżeli jest to wskazane, uzupełniająco stosuje się również:

5. Leczenie dietetyczne. Badania ostatnich lat wskazują, że prawidłowe żywienie może mieć duży wpływ na płodność kobiet i mężczyzn. Stosowanie zasad dobrze zbilansowanej diety, która dostarcza wszystkich niezbędnych składników odżywczych, opartej w przewadze na produktach roślinnych, z jednoczesnym unikaniem nadmiernego spożycia energii, węglowodanów i izomerów trans kwasów tłuszczowych, ma istotne znaczenie w zapobieganiu zaburzeniom płodności. Proporcje spożycia różnych grup produktów spożywczych opierają się na Piramidzie zdrowego żywienia publikowanej przez Instytut Żywności i Żywienia. W szczególnych sytuacjach klinicznych zalecane są diety specjalistyczne:

- dieta niskowęglowodanowa przy insulinooporności w zespole policystycznych jajników,

- dieta eliminacyjna w przypadku chorób o podłożu immunologicznym, alergii, nietolerancji pokarmowych.

\section{Dietetycy podkreślają, że:}

[...] płodności kobiet sprzyja dobrze zbilansowana dieta oparta przede wszystkim na żywności pochodzenia roślinnego, bogata w warzywa i owoce, zbożowe produkty z pełnego ziarna, a także wybór tłuszczów roślinnych dostarczających dużych ilości jednonienasyconych kwasów tłuszczowych. Istotne jest wykluczenie z jadłospisu twardych margaryn, fast-foodów, chipsów, zup w proszku, ciastek i słodyczy, przede wszystkim przemysłowo wytwarzanych, ale także domowych ciast i innych potraw zawierających znaczne ilości cukru. Podstawowe znaczenie ma utrzymanie prawidłowej masy ciała. [...] istnieją także dane sugerujące, że dieta bogatotłuszczowa, bogatobiałkowa, a jednocześnie uboga w węglowodany, błonnik, foliany i antyoksydanty, wiąże się z dużym ryzykiem nasilenia niepłodności u mężczyzn9.

6. Wsparcie psychologiczne. Przekazy osób dotkniętych niepłodnością wskazują na duży wpływ presji bliższego i dalszego otocznia na indywidualne po-

${ }^{8}$ Tamże, s. 189.

9 D. Szostak-Węgierek, Dieta sprzyjająca płodności, w: M. Barczentewicz i in., Zdrowie prokreacyjne NaProTECHNOLOGY w diagnozowaniu i leczeniu niepłodności, Poznań 2010, s. 20. 
strzeganie swojej sytuacji i cierpienia, które w związku z bezdzietnością je dotyka. W odczuwanych przez nie emocjach pojawia się gniew, złość, poczucie winy, a nawet doszukiwanie się kary za wcześniejsze czyny. W związku z tym

[...] zasadne jest diagnozowanie i poddawanie terapii psychologicznych przyczyn i skutków niepłodności. Celem psychoterapii jest mobilizowanie sił psychicznych pacjentów do walki z chorobą i zwiększenie skuteczności stosowanych metod leczenia. Równocześnie zakłada się, że podjęcie psychoterapii wpłynie na poprawę jakości życia osób dotkniętych niechcianą bezdzietnością poprzez minimalizowanie psychicznych przyczyn i skutków niezamierzonej bezdzietności ${ }^{10}$.

W literaturze dotyczącej leczenia psychologicznych aspektów niepłodności dostępne są dane, które wskazują, że interwencja psychologa w terapii niepłodności zwiększa szanse na sukces leczenia, czyli uzyskanie ciąży, a w pewnych sytuacjach jest sposobem leczenia alternatywnego dla tych, którzy nie poddają się leczeniu opartemu na uznanych zdobyczach wiedzy medycznej ${ }^{11}$.

7. Wsparcie duchowe. Dla osób wierzących nie bez znaczenia jest ukazanie problemu bezdzietności w perspektywie wiary, w odniesieniu do Pisma Świętego. Potrzebna jest obecność kapłana, który w pewnych konkretnych sytuacjach służy wsparciem, kompensując w ten sposób brak zrozumienia ze strony najbliższego otoczenia .

\section{B. Leczenie chirurgiczne - Surgical NaProTECHNOLOGY}

Postępowanie chirurgiczne prowadzone jest w naprotechnologii równolegle z zachowawczym, które może być niewystarczające do usunięcia przeszkód w powrocie do zdrowia prokreacyjnego. Najczęstszymi wskazaniami do postępowania zabiegowego w niepłodności są:

- endometrioza;

- zespół policystycznych jajników;

- choroba zrostowa miednicy;

- niedrożność bliższej części jajowodów;

- niedrożność dalszej części jajowodów;

10 J. Łuczak-Wawrzyniak, Niepłodność-aspekty psychologiczne, w: M. Barczentewicz i in., Zdrowie prokreacyjne NaProTECHNOLOGY $w$ diagnozowaniu i leczeniu niepłodności. Poznań 2010, s. 14.

${ }^{11}$ K. Hammarberg, J.R. Fisher, K.H. Wynter, Psychological and social aspects of pregnancy, childbirth and early parenting after assisted conception: a systematic review, Hum Reprod Update 2008; 14, s. 395-414. 
a poza tym inne sytuacje kliniczne:

- bolesne miesiączki, bóle miednicy;

- obfite i przedłużające się krwawienia miesiączkowe mające u podłoża mięśniaki macicy;

- torbiele jajników ${ }^{12}$.

Surgical NaProTECHNOLOGY - to specjalistyczna chirurgia ginekologiczna, która kładzie szczególny nacisk na użycie technik operacyjnych zmniejszających możliwość powstania zrostów pooperacyjnych. Należy podkreślić, że nie ma jednego środka antyzrostowego lub jednej metody, jest to zbiór zasad, jakimi powinno się posługiwać na różnych etapach operacji, zwracając wystarczającą uwagę na szczegóły. Osiągnięciu założonego celu służy zachowanie wysokiej kultury operacyjnej poprzez zastosowanie:

- nowoczesnych technik przeciwzrostowych;

- hemostatycznej techniki cięcia;

- starannego doboru szwów;

- szczegółowego doboru narzędzi;

- specjalistycznych środków przeciwzrostowych;

- użycie lasera;

- technik mikrochirurgicznych ${ }^{13}$.

Surgical NaProTECHNOLOGY to w przeważającej mierze chirurgia naprawcza i rekonstrukcyjna pozwalająca przywrócić fizjologiczne funkcje narządów rozrodczych - naturalną płodność.

\section{Etap III. Odliczanie efektywnych cykli}

Ten etap w strategii postępowania ma na celu utrzymanie 12 efektywnych, prawidłowych cykli miesiączkowych poprzez

- obserwacje według Modelu Creighton (ocenę cyklu),

- monitorowanie poziomu hormonów,

- interwencje zabiegowe (w razie określonych wskazań).

\footnotetext{
${ }^{12}$ T.W. Hilgers, The Medical and Surgical Practice of NaProTECHNOLOGY, dz. cyt.

${ }^{13}$ Tamże.
} 


\section{Krok trzeci}

Kontynuowanie prowadzenia obserwacji i zapisu karty oraz stosowanie się do wprowadzonych przez instruktora i lekarza zaleceń. Nadal odbywają się co pół roku spotkania z instruktorem CrMS.

Przedstawiona powyżej strategia postępowania $\mathrm{w}$ naprotechnologii dotyczy problemu niepłodności. Przywołana poniżej rycina z podręcznika naprotechnologii profesora Thomasa Hilgersa bardzo obrazowo rekapituluje to podejście w formie drabiny terapeutycznej, na której szczeblach osadzone są zastosowane metody postępowania. Na pierwszym szczeblu tejże drabiny sadowi się Creighton Model Fertility Care System - podstawa działania systemu. Kolejne etapy: diagnostyka, terapia aż do najwyższego szczebla, gdzie w przypadku wyczerpania możliwości metody proponuje się rozważenie rozwiązania w postaci procedury adopcyjnej.

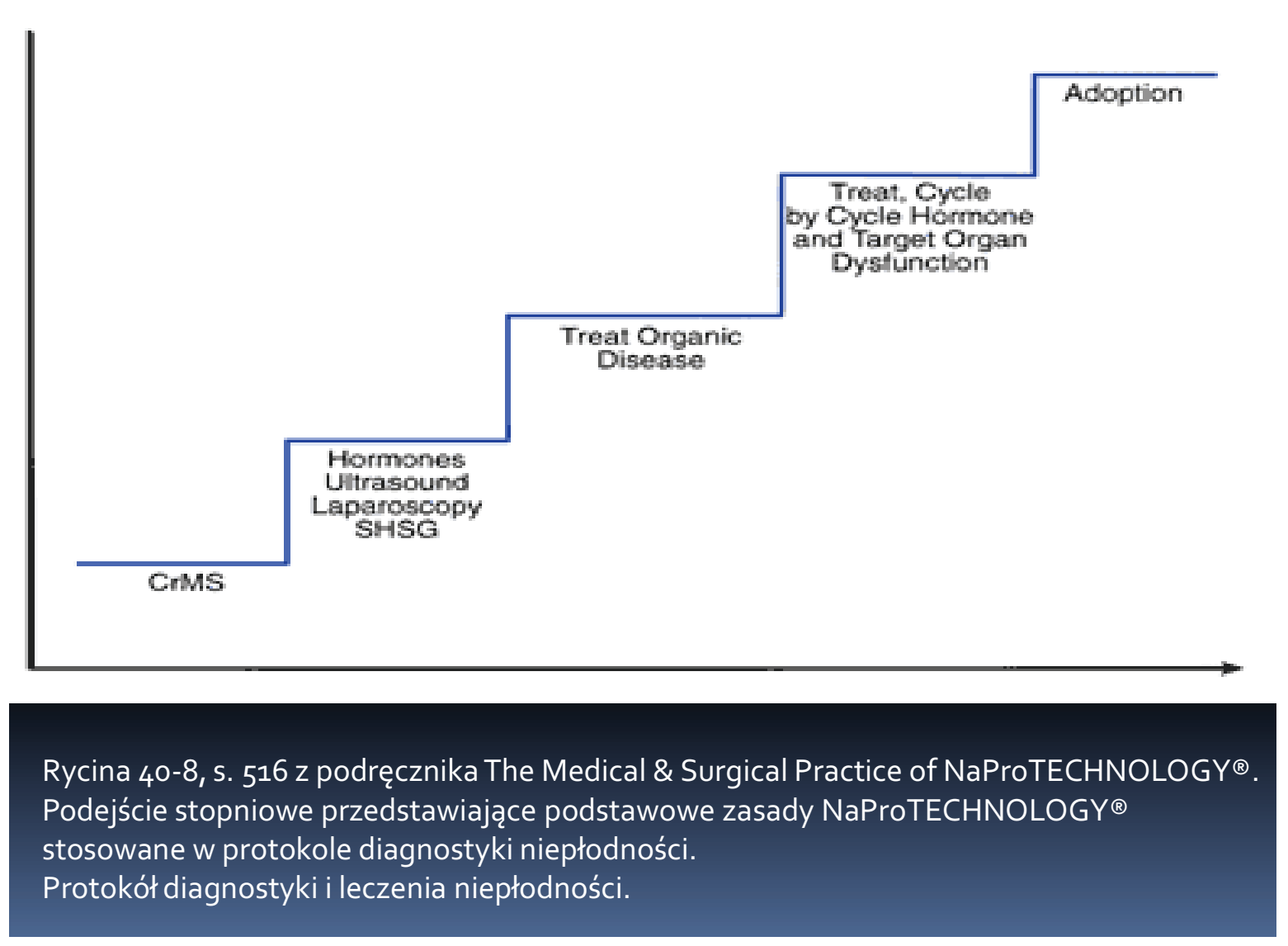

Należy więc mieć na uwadze fakt, że

„NaProTECHNOLOGY nie jest metodą skuteczną w 100\%. Istnieją sytuacje, gdzie terapia niepłodności jest niemożliwa i te małżeństwa pozostaną bezpłodne. W takich sytuacjach w ramach NaProTECHNOLOGY pary przygotowywane 
są do adopcji dzieci" "14. Istnieją również sytuacje ograniczające zastosowanie tej metody. „Naprotechnologii nie powinno się stosować w przypadku azoospermii, która utrzymuje się pomimo diagnozy i leczenia, rozpoznania menopauzy lub trwałego obustronnego zamknięcia jajowodów niemożliwego do skorygowania w drodze mikrozabiegu korekcyjnego"15.

\section{Skuteczność naprotechnologii}

W tym miejscu należy odnieść się do skuteczności naprotechnologii. Skumulowane wyniki: wskaźnik ciąż po leczeniu naprotechnologią z powodu niepłodności przedstawiają się następująco odpowiednio w przedziałach czasowych: do 12 miesięcy uzyskano $44 \%$ ciąż, do 24 miesięcy - $62 \%$ ciąż, w 48 miesięcy od rozpoczęcia leczenia $71 \%$.

Wyniki leczenia, kiedy rozpoznaną przyczyną niepłodności była endometrioza: 45\% ciąż do 12 miesięcy, 65\% - do 24 miesięcy, 78\% - do 36 miesięcy.

Skumulowany wskaźnik ciąż dla pacjentek z zespołem policystycznych jajników: $40 \%$ po 12 miesiącach, $65 \%$ po 24 miesiącach, do $90 \%$ po 48 miesiącach $^{16}$.

Przywołane dane badawcze pokazują, że zastosowanie naprotechnologii w terapii niepłodności może być skuteczne, a nawet o wiele skuteczniejsze niż dominujące podejście do leczenia niepłodności. Cenne w tym aspekcie są również prace profesora Josepha B. Stanforda z Uniwersytetu w Utah (USA). Tabela na następnej stronie prezentuje porównanie różnych wyników leczenia niepłodności.

Jako komentarz niech posłużą wnioski z publikacji profesora Stanforda:

Porównanie podejść reprodukcyjnych i naprawczych (naprotechnologii) nie jest obecnie wyczerpujące ze względu na brak w pełni porównywalnych danych w zakresie leczonych populacji. Mimo to dostępne dane wskazują na podobne współczynniki urodzeń żywych oraz znacznie mniejsze współczynniki ciąż mnogich i małej urodzeniowej masy ciała w przypadku naprawczej medycyny prokreacyjnej (naprotechnologii). IVF wiąże się także z innymi rzadszymi skutka-

${ }^{14}$ B. Bassa, Zastosowanie NaProTECHNOLOGY w diagnostyce i leczeniu niepłodności matżeńskiej, w: Rodzina i rodzicielstwo. Między tradycją a wspótczesnościa, red. A. Skreczko, B. Bassa, Z. Struzik, Warszawa 2014, s. 247.

15 J.B. Stanphord, Naprawcza medycyna prokreacyjna a medycyna reprodukcyjna: ocena priorytetów i wyniki, w: Profilaktyka, rozpoznanie przyczyn i leczenie niepłodności, red. J. Gadzinowski, Poznań 2016, s. 69.

${ }^{16}$ J.B. Stanford, T.A. Parnell, Ph.C. Boyle, Outcomes from treatment of infertility with natural procreative technology in an Irish general practice, „Journal of the American Board of Family Medicine" 2008 Sep-Oct;21(5), s. 375-384. 
Tabela 1.

Porównanie wyników różnych sposobów leczenia niepłodności

\begin{tabular}{|c|c|c|c|c|c|c|c|c|c|c|c|c|}
\hline $\begin{array}{l}\text { Sposób } \\
\text { leczenia }\end{array}$ & Lokalizacja & $\mathrm{N}$ & $\begin{array}{c}\text { Rok } \\
\text { publikacji }\end{array}$ & $\begin{array}{l}\text { Średnia } \\
\text { wieku } \\
\text { kobiet }\end{array}$ & $\begin{array}{c}\text { Czas } \\
\text { starania się } \\
\text { o dziecko }\end{array}$ & $\begin{array}{c}\text { Wcześniejsze } \\
\text { ciąże } \\
(\mathrm{w} \%)\end{array}$ & $\begin{array}{l}\text { Ramy } \\
\text { czasowe }\end{array}$ & $\begin{array}{c}\text { Wynik } \\
\text { surowy } \\
\text { (w \%) }\end{array}$ & $\begin{array}{l}\text { Wynik } \\
\text { skorygo- } \\
\text { wany }\end{array}$ & $\begin{array}{c}\text { Bliźnięta } \\
\text { lub ciąże } \\
\text { mnogie } \\
(\mathrm{w} \%)\end{array}$ & $\begin{array}{l}\text { Masa uro- } \\
\text { dzeniowa } \\
<2500 \mathrm{~g} \\
(\mathrm{w} \%)\end{array}$ & Odwołania \\
\hline Napro & Irlandia & 1072 & 2008 & 358 & 5,6 lat & 47 & 2 lata & $\begin{array}{l}26 \% \\
\text { urodzeń }\end{array}$ & $\begin{array}{c}53 \% \\
\text { urodzeń }\end{array}$ & 5 & 5 & [30] \\
\hline Napro & Kanada & 108 & 2012 & 354 & 3,2 lata & 44 & 2 lata & $\begin{array}{c}38 \% \\
\text { urodzeń }\end{array}$ & $\begin{array}{c}66 \% \\
\text { urodzeń }\end{array}$ & 0 & 15 & [46] \\
\hline IVF & Holandia & 1351 & 2007 & 328 & 3,6 lat & 47 & 1 rok & $\begin{array}{l}42 \% \\
\text { ciąż }\end{array}$ & $\begin{array}{l}65 \% \\
\text { ciąż }\end{array}$ & 22 & bd & [34] \\
\hline IVF & $\begin{array}{c}\text { Wielka } \\
\text { Brytania }\end{array}$ & 107347 & 2016 & 341 & 4 lata & bd & $\sim 1,5$ roku$^{*}$ & $\begin{array}{c}42 \% \\
\text { urodzeń }\end{array}$ & $\begin{array}{c}57 \% \\
\text { urodzeń }\end{array}$ & 25 & bd & [59] \\
\hline IVF & USA & 246740 & 2012 & 355 & bd & bd & $\sim 1,5 \mathrm{roku}^{* *}$ & $\begin{array}{l}\sim 55 \% \\
\text { urodzeń }\end{array}$ & $\begin{array}{l}\sim 75 \% \\
\text { urodzeń }\end{array}$ & 47 & 32 & {$[60,61]$} \\
\hline
\end{tabular}

bd - brak danych

* - do trzech cykli poboru komórek jajowych do IVF, z wszystkimi późniejszymi transferami zarodków, w tym cyklami transferu zamrożonych zarodków

** - do czterech cykli poboru komórek jajowych do IVF, świeżo pobranych i/lub zamrożonych

Źródło: J.B. Stanphord MD, MSPH,CFCMC, Naprawcza medycyna prokreacyjna a medycyna reprodukcyjna: ocena priorytetów i wyniki, w: Profilaktyka, rozpoznanie przyczyn i leczenie niepłodności, red. J. Gadzinowski, Poznań 2016, s. 72. 
mi niepożądanymi, jak np. wadami wrodzonymi, w przyszłości okaże się, czy te rzadkie skutki niepożądane uda się ograniczyć dzięki zastosowaniu naprawczej medycyny prokreacyjnej. Wyniki te przemawiają za zastosowaniem naprotechnologii jako terapii niepłodności pierwszego rzutu i podkreślają znaczenie dalszych badań w kwestii oceny i szerzenia jej zakresu oraz podejść do leczenia w ramach naprawczej medycyny prokreacyjnej ${ }^{17}$.

\section{Inne wskazania dla naprotechnologii}

Postępowanie wygląda nieco inaczej w przypadku zaburzeń hormonalnych, zespołu napięcia przedmiesiączkowego czy depresji poporodowej. W Polsce utarło się myślenie, które wiąże NaProTECHNOLOGY z leczeniem niepłodności, podczas gdy metoda znajduje zastosowanie w wielu innych przytoczonych poniżej problemach zdrowia prokreacyjnego, jakimi są:

- endometrioza;

- zespół policystycznych jajników;

- torbiele czynnościowe jajników;

- bolesne miesiączkowanie;

- zespół napięcia przedmiesiączkowego;

- nieregularne lub nieprawidłowe krwawienia;

- zaburzenia hormonalne;

- nieprawidłowa wydzielina z dróg rodnych kobiety;

- poronienia, poronienia nawykowe;

- depresja poporodowa.

\section{Mężczyzna w naprotechnologii}

Płodność małżeńską należy rozważać jako całość, a więc zdolność zarówno mężczyzny, jak i kobiety do poczęcia dziecka. Jeżeli kobieta ma problemy z zajściem w ciążę w poszukiwaniu rozwiązania należy wziąć pod uwagę: ją, mężczyznę albo nawet oboje. Publikacje medyczne wskazują na następujące przyczyny występowania męskiego czynnika niepłodności:

- zaburzenia hormonalne związane z zakłóceniem działania przysadki mózgowej i podwzgórza, trzustki lub tarczycy;

${ }^{17}$ J.B. Stanphord, Naprawcza medycyna prokreacyjna a medycyna reprodukcyjna: ocena priorytetów i wyniki, w: Profilaktyka, rozpoznanie przyczyn i leczenie niepłodności, dz. cyt., s. 73. 
- zaburzenia chromosomalne (nieprawidłowy kariotyp);

- niedobory testosteronu;

- urazy mechaniczne;

- hipogonadyzm;

- niedrożność lub brak nasieniowodów, stany zapalne i pourazowe w ich obrębie, żylaki powrózka nasiennego;

- choroby ogólnoustrojowe leczone lekami upośledzającymi działanie jąder (np. chorobę wrzodową żołądka i dwunastnicy, niektóre leki hormonalne, leki obniżające ciśnienie, niektóre antybiotyki);

- infekcje wirusowe i bakteryjne (np. wirusowe zapalenie przyusznic);

- choroby autoimmunologiczne (w tym niektóre alergie);

- immunologiczne;

- choroby przebiegające z wysoką gorączką (jeśli była to jedyna przyczyna pogorszenia wyników, obserwowana jest poprawa jakości nasienia, zwykle po ok. 6 miesiącach od ustąpienia gorączki);

- podwyższona temperatura w mosznie (np. wnętrostwo), zbyt obcisła bielizna, dużo czasu spędzanego w pozycji siedzącej, w tym np. wielogodzinna praca z laptopem trzymanym na udach;

- kontakt z czynnikami toksycznymi.

Najważniejszym badaniem laboratoryjnym dla mężczyzny jest badanie nasienia:

Przeprowadza się badanie parametrów nasienia. sprawdza się jakość, szybkość i ilość plemników w nasieniu, czas upłynnienia, objętość, lepkość, wygląd ejakulatu, pH, odsetek żywych i ruchliwych plemników, liczbę plemników w $1 \mathrm{ml}$ nasienia, obecność i ewentualnie stopień aglutynacji plemników. Dodatkowo wprowadza się ocenę morfologii plemników ,to znaczy odsetek prawidłowo zbudowanych plemników oraz odsetek różnych wad budowy dotyczących główki, wstawki i witki plemnika, odsetek komórek spermatogenezy obecnych w ejakulacie, liczbę leukocytów w $1 \mathrm{ml}$ nasienia oraz liczbę komórek nabłonkowych i erytrocytów ${ }^{18}$.

Należy przypomnieć, o czym była już mowa w części dotyczącej leczenia niepłodności, że wyklucza się pobranie nasienia poprzez masturbację. Badania naukowe potwierdzają wyższą wartość diagnostyczną nasienia pobranego w trakcie naturalnego aktu małżeńskiego. Duże znaczenie diagnostyczne ma również tak zwany test postkoitalny, który powinien być wykonany w okresie okołoowulacyjnym, w tym czasie śluz zwykle ma najlepszą jakość. Do ustala-

${ }^{18}$ B. Bassa, Zastosowanie NaProTECHNOLOGY w diagnostyce i leczeniu niepłodności matżeńskiej, dz. cyt., s. 245. 
nia okresu okołowulacyjnego służy obserwacja na podstawie Creighton Model Fertility Care System. Przeprowadzenie testu w niewłaściwym, sztywno ustalonym okresie cyklu kobiecego, skutkuje osiągnięciem niemiarodajnych wyników. Test pozwala ocenić przeżywalność i zachowanie plemników w śluzie szyjki macicy. Ocenia się również obecność przeciwciał w nasieniu ${ }^{19}$. Doktor Hilgers podkreśla również specyficzną rolę obserwacji Creighton Model Fertility Care System u pacjentów, których problemy z poczęciem związane są z zaburzonymi parametrami nasienia, np. w ciężkiej oligospermii. Obserwacja cyklu pozwala podjąć współżycie w takim momencie, kiedy istnieją najlepsze warunki do poczęcia z punktu widzenia jakości śluzu. W ten sposób można kompensować niedobory płodności mężczyzny, wykorzystując lub nawet poprawiając płodność kobiety ${ }^{20}$. Podobnie jak u kobiety, w przypadku zaburzeń hormonalnych znajduje zastosowanie leczenie hormonalne, środki stymulujące spermatogenezę, antybiotyki w przypadku stanów zapalnych męskiego układu płciowego, witaminy i mikroelementy. Nie bez znaczenia jest zmiana stylu życia (ograniczenie używek, racjonalne żywienie, ruch na świeżym powietrzu) czy wyeliminowanie (w miarę możliwości) czynników szkodliwych w pracy. W wyjątkowych sytuacjach znajduje zastosowanie andrologia operacyjna, na przykład operacje żylaków powrózka nasiennego, operacyjna korekcja jądra niezstąpionego czy zabiegi mikrochirurgiczne ${ }^{21}$.

\section{SPICE}

Omawiając naprotechnologię, nie sposób nie wspomnieć o nauce programu SPICE. Jest to skrót od angielskich terminów opisujących różne sfery życia małżonków:

- SPIRITUAL DUCHOWOŚĆ

- PHYSICAL FIZYCZNOŚĆ

- INTELLECTUAL INTELEKT

- CREATIVE/COMMUNICATIVE KREATYWNOŚĆ/KOMUNIKACJA

- EMOTIONAL/PSYCHOLOGICAL EMOCJE/PSYCHIKA

19 T.W. Hilgers, Reproductive Anatomy and Physiology: A Primer for FertilityCare Professionals, Omaha [USA, Nebraska] 2002, s. 167.

${ }^{20}$ T.W. Hilgers, The NaProTECHNOLOGY Revolution. Unleashing the Power in a Woman's Cycles, dz. cyt., s. 310-312.

${ }^{21}$ M. Semczuk, M. Kurpisz, Leczenie zaburzeń męskiej płodności, w: ciż, Andrologia, Warszawa $2006^{2}$, s. 394-452. 
W wolnym thumaczeniu oznacza to ubogacenie sfery zachowań seksualnych. Doktor Hilgers włącza naukę SPICE do cyklu spotkań z użytkownikami Creighton Model Fertility Care System. Poznając SPICE, małżonkowie uczą się nowego zasobu zachowań i komunikacji między sobą na drodze pozagenitalnej. Pożądanym skutkiem jest ubogacenie ich behawioru w sferze seksualnej. Przykładowo w sferze duchowej proponuje się podjęcie wspólnej modlitwy. W sferze fizycznej należy zadbać, aby małżonkowie spali razem, nie w osobnych sypialniach, uczy się ich afirmującego dotyku, który nie musi prowadzić w każdym przypadku do zbliżenia fizycznego. Kładzie się nacisk na wzajemne wspieranie $\mathrm{w}$ rozwoju intelektualnym oraz na poszerzenie sposobów komunikowania się pomiędzy małżonkami, na przykład poprzez pisanie do siebie listów. Na płaszczyźnie emocjonalnej ważne jest stworzenie sobie wzajemnie przestrzeni do akceptacji i ekspresji własnych zachowań i emocji, a także pielęgnowanie czasu przeznaczonego tylko dla siebie wzajemnie ${ }^{22}$.

\section{Badania naukowe w naprotechnologii}

Jednym z najczęstszych zarzutów przeciwko naprotechnologii jest brak badań naukowych i naukowych podstaw tej metody leczenia. Wszystko zależy od słowa-klucza, jakiego użyje się przy wyszukiwaniu w bazie publikacji medycznych. Jeżeli wpiszemy słowo IVF spotkamy się z setkami tysięcy rekordów. Jeżeli wpiszemy słowo „NaProTECHNOLOGY”, to znajdą się tylko dwa badania: J.B. Stanford, T.A. Parnell, Ph.C. Boyle, Outcomes From Treatment of Infertility With Natural Procreative Technology in an Irish General Practice (2008) oraz E. Tham, K. Schliep, J. Stanford, Natural procreative technology for infertility and recurrent miscarriage: Outcomes in a Canadian family practice (2012). W przypadku gdy zaczniemy wyszukiwać według słów odnoszących się do stosowanych w postępowaniu metodą naprotechnologii procedur, np.: laparoskopia, histerosalpingografia, radiologia zabiegowa, chirurgia ginekologiczna, czy sposobów diagnozowania, np.: śluz płodny, naturalne metody planowania rodziny, wyniki będą bardzo liczne. Liczba rekordów na te szczegółowe tematy jest o wiele większa, a lekarze konsultanci medyczni naprotechnologii diagnozują i leczą na podstawie zawartej w nich wiedzy. Różnica polega na tym, że procedury naprotechnologii są personalizowane do sytuacji zdrowotnej konkretnej kobiety i wprowadzane w odpowiednim momencie cyklu, aby diagnostyka i terapia przynosiły jak najwięcej korzyści przy ograniczeniu do minimum możliwych działań niepożądanych. $\mathrm{O}$ prowadzonych i planowanych pracach badawczych mówi natomiast jeden

22 T.W. Hilgers, An introductory Booklet for New Users, Omaha [USA, Nebraska] 2001, s. 35-38. 
z prekursorów naprotechnologii w Polsce doktor Maciej Barczentewicz, prezes Zarządu Fundacji Instytut Leczenia Niepłodności Małżeńskiej im. Jana Pawła II w Lublinie:

We współpracy z prof. Stanfordem opracowaliśmy wyniki naszego ośrodka w Lublinie z lat 2008-2012. Profesor chce to opublikować w czasopiśmie międzynarodowym jako trzecią pracę na temat tej metody leczenia. Będzie ona prezentować początki napro w Polsce. Jest to praca retrospektywna, na podstawie kartotek pacjentek - zawiera dane na temat tego, jakie były rozpoznania i jakie efekty leczenia (liczba poczęć, żywych urodzeń i poronień).

Prowadzone jest także badanie prospektywne iNEST: The international NaProTechnology Evaluation and Surveillance of Treatment (Międzynarodowa Ewaluacja i Monitorowanie Skuteczności NaProTechnology w leczeniu niepłodności i poronień). Jest ono jeszcze bardziej miarodajne, gdyż już na początku założony w nim został zakres danych, jakie są zbierane, a do niektórych z nich nie było dostępu w badaniu retrospektywnym. Zostanie zakończone 31 grudnia 2016 i wyniki również zostaną opublikowane. $\mathrm{W}$ projekcie brały udział ośrodki z różnych krajów, mierzy on między innymi skuteczność NaProTECHNOLOGY. Najnowszy projekt naukowy to STORRM: Surveillance of Treatment and Outcomes in Restorative Reproductive Medicine - badanie podobne do iNEST, ale z rozszerzeniem na inne metody rozpoznawania płodności niż Model Creightona ${ }^{23}$.

Podsumowując, należy podkreślić, że naprotechnologia jest nową gałęzią wiedzy medycznej poświęconą zdrowiu kobiety. Wykorzystuje nowoczesne techniki chirurgiczne, leczenie hormonalne, procedury ultrasonograficzne w ścisłej korelacji z edukacją o cyklu kobiecym na podstawie obserwacji biomarkerów cyklu płodności. Naprotechnologia jest rewolucyjną odpowiedzią na techniki wspomaganego rozrodu (medycynę reprodukcyjną) ${ }^{24}$.

Kończąc, należy wspomnieć, że specjaliści naprotechnologii kierują się kodeksem etycznym. Wykluczone jest stosowanie antykoncepcji, aborcji, in vitro czy jakichkolwiek innych technik wspomaganej prokreacji. Warto podkreślić, że w naprotechnologii myśli się o płodności jako o fakcie naturalnym, o fizjologii. Płodność nie jest traktowana jako choroba, zaś lecząc niepłodność, szuka się ukrytych przyczyn, które za nią stoją, starając się je zdiagno-

${ }^{23}$ E. Wiater, Naprotechnologia to nie medycyna? „Pozwólmy mówić faktom”, http://www. leczenie-nieplodnosci.pl/pl/aktualnosci/naprotechnologia-to-nie-medycyna-pozwolmy-mowicfaktom/ [dostęp: 18.11.2016].

${ }^{24}$ T.W. Hilgers, The NaProTECHNOLOGY Revolution. Unleashing the Power in a Woman's Cycles, dz. cyt., s. 396-397. 
zować i wyleczyć, nie jak przypadku in vitro, które omija ten etap, proponując kosztowne i nieetyczne rozwiązanie.

\author{
NAPROTECHNOLOGY - \\ GOOD DIAGNOSTICS AND EFFECTIVE TREATMENT
}

\title{
Summary
}

NaProTECHNOLOGY (Natural Procreative Technology), a new area of medical knowledge devoted to the reproductive health of a woman developed in the seventies and eighties of the last century by Dr. Thomas Hilgers from Omaha, Nebraska (USA). Thomas Hilgers is a practicing obstetrician gynecologist, now a director Institute of Pope Paul VI.

NaProTechnology was created as a response to the message of Pope Paul VI encyclical Humanae Vitae to the people of science, in order to prove the method of natural family planning that would correspond to ethical requirements in the aspect of the Church's teaching.

Several years of scientific research verified by statistical methods and clinical practice have allowed to develop a new method of natural family planning: Creighton Model Fertility Care System which is the basis for implementing professional medical treatment in fertility disorders and other disorders of the women's cycle with the patented name NaProTechnology.

Currently, NaProTechnology is one of the main trends in the corrective medicine of procreation where the emphasis is on shaping a new culture of human life and respect for children's rights, which begins in a natural way. In the article the author presents the diagnostic and therapeutic process used in the new method as well as the advantages and limitations of the above method of selected clinical situations based on current medical knowledge.

Stowa kluczowe: naprotechnologia; Creighton Model Fertility Care System; naprawcza medycyna prokreacji; niepłodność

Keywords: NaProTECHNOLOGY; Creighton Model Fertility Care System; Corrective Medicine of Procreation; infertility

\section{BIBLIOGRAFIA}

Barczentewicz M., Naprotechnology jako narzędzie diagnostyki i leczenia niepłodności i innych chorób, w: Naturalne planowanie rodziny $w$ ujęciu wybranych dyscyplin naukowych, red. W. Wieczorek i in, Lublin 2008, s. 229-238. 
Bassa B., Zastosowanie NaProTECHNOLOGY w diagnostyce i leczeniu niepłodności matżeńskiej, w: Rodzina i rodzicielstwo. Między tradycja a wspótczesnościa, red. A. Skreczko, B. Bassa, Z. Struzik, Warszawa 2014, s. 239-249.

Hammarberg K., Fisher J.R., Wynter K.H., Psychological and social aspects of pregnancy, childbirth and early parenting after assisted conception: a systematic review, Hum Reprod Update 2008; 14, s. 395-414.

Hilgers T.W., An introductory Booklet for New Users, Omaha [USA, Nebraska] 2001.

Hilgers T.W., The Medical and Surgical Practice of NaProTECHNOLOGY, Omaha [USA, Nebraska] 2004.

Hilgers T.W., The NaProTECHNOLOGY Revolution. Unleashing the Power in a Woman's Cycles, New York 2010.

Hilgers T.W., Reproductive Anatomy and Physiology: A Primer for FertilityCare Professionals, Omaha [USA, Nebraska] 2002.

Kieniewicz P., NaProTECHNOLOGY, w: P. Kieniewicz, Bioetyczny labirynt, Licheń Stary 2013, s. 90-91.

Łuczak-Wawrzyniak J., Niepłodność-aspekty psychologiczne, w: M. Barczentewicz i in., Zdrowie prokreacyjne NaProTECHNOLOGY w diagnozowaniu i leczeniu niepłodności, Poznań 2010, s. 11-15.

Paweł VI, Humanae vitae, (25 lipiec 1968).

Semczuk M., Kurpisz M., Leczenie zaburzeń męskiej płodności, w: M. Semczuk, M. Kurpisz, Andrologia, Warszawa $2006^{2}$, s. 394-452.

Stanphord J.B., Naprawcza medycyna prokreacyjna a medycyna reprodukcyjna: ocena priorytetów $i$ wyniki, w: Profilaktyka, rozpoznanie przyczyn i leczenie niepłodności, red. J. Gadzinowski, Poznań 2016, s. 65-77.

Stanford J.B., Parnell T.A., Boyle Ph.C., Outcomes from treatment of infertility with natural procreative technology in an Irish general practice, „Journal of the American Board of Family Medicine" 2008 Sep-Oct;21(5), s. 375-384.

Szostak-Węgierek D., Dieta sprzyjająca płodności, w: M. Barczentewicz i in., Zdrowie prokreacyjne NaProteCHNOLOGY w diagnozowaniu i leczeniu niepłodności, Poznań 2010, s. 19-23.

Wiater E., Naprotechnologia to nie medycyna? „Pozwólmy mówić faktom”, Artykuł na stronie Instytutu Leczenia Niepłodności im. Jana Pawła II,18.11.2016; http://www.leczenie-nieplod nosci.pl/pl/aktualnosci/naprotechnologia-to-nie-medycyna-pozwolmy-mowic-faktom/ [dostęp: 01.02.2017].

JACEK Czerniak, absolwent wydziału lekarskiego Uniwersytetu Medycznego im. Karola Marcinkowskiego w Poznaniu, lekarz medycyny, specjalista w dziedzinie chorób wewnętrznych, medycyny rodzinnej i medycyny paliatywnej, NFPMC-konsultant medyczny NaProTechnology, aktualnie pracuje w Ośrodku Wsparcia Płodności NaProTechnologia w Licheniu Starym oraz w Oddziale Hospicjum im. św. Stanisława Papczyńskiego w Licheniu Starym, od początku pracy zawodowej zajmuje się nauczaniem, szkoleniem i promocją naturalnych metod rozpoznawania płodności-instruktor i nauczyciel metody wielowskaźnikowej podwójnego sprawdzenia (tzw. angielskiej). Zainteresowania: diagnostyka ultrasonograficzna w medycynie - uzyskał certyfikat Polskiego Towarzystwa Ultrasonograficznego w zakresie ultrasonografii ogólnej. 